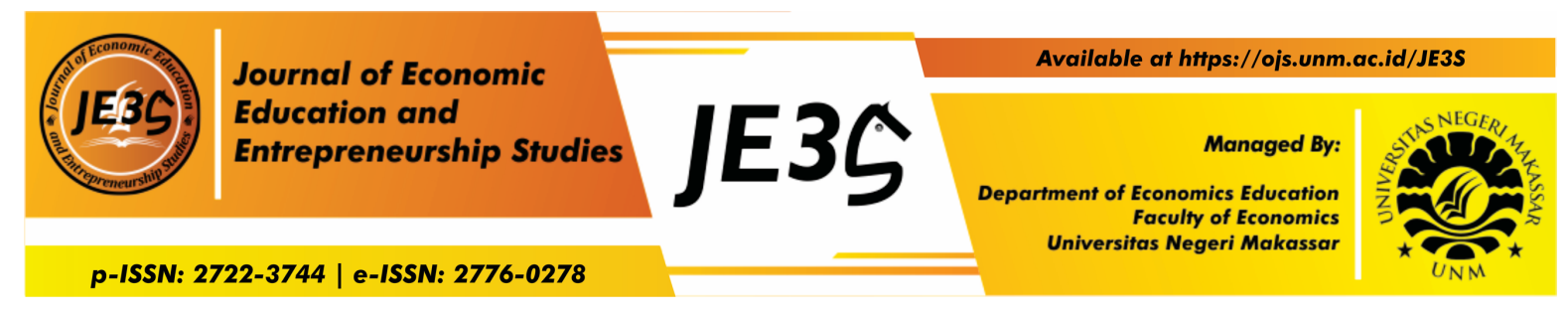

\title{
Determinan Tingkat Literasi Keuangan Siswa Sekolah Menengah (Studi Komparatif Indonesia dan Vietnam)
}

Fatih Atsaris Sujud ${ }^{1}$, Khasan Setiaji ${ }^{2 *}$

${ }^{1,2}$ Fakultas Ekonomi Universitas Negeri Semarang

Article History

Received April 24, 2020

Approved May 21, 2020

Published June 30, 2020

$\frac{\text { Keywords }}{\text { Financial Literacy, Gender, Education, }}$

Income, Students

\begin{tabular}{lc}
\hline \multicolumn{2}{c}{ JEL Classification } \\
\hline G53 \\
\hline
\end{tabular}

How to Cite

Sujud, F.A., \& Setiaji, K. 2020.

Determinan Tingkat Literasi Keuangan

Siswa Sekolah Menengah (Studi

Komparatif Indonesia dan Vietnam).

Journal of Economic Education and

Entrepreneurship Studies, 1(1), 1-15.

\begin{abstract}
Financial literacy is an individual ability to make decision on it's financial regulation. An individu has to have knowledge and skill to set his financial resources effectively to gain his prosperity. Financial literacy is influenced by many factors, such as gender, education and income of parent those become the purpose of this research. The population of this study was students of SMA Hidayatullah and THPT Tran Nhan Tong. Saturated sampling was used as the method of sampling from 246 respondents. In analyzing the data, the writer used Mann Whitney method. The result showed that there was difference between gender and education of parent on influencing financial literacy under 0.05 asymptomatic significance, there was no difference income of parent on influencing towards financial literacy. Meanwhile there was difference of both countries' financial literacy. For the suggestion, the students are expected to be more diligent to learn and apply their finanncial knowledge, meanwhile for the future researcher, is expected to find other variables those have big impact toward an individual's financial literacy to get many more varied researches.
\end{abstract}

\footnotetext{
*Khasan Setiaji

Kampus Sekaran, Gunungpati,

Kota Semarang, Jawa Tengah, 50229

e-mail: setiaji@mail.unnes.ac.id
}

(C) 2020 Universitas Negeri Makassar

\section{PENDAHULUAN}

Beberapa tahun terakhir, semua negara dalam dunia perekonomian semakin khawatir mengenai level literasi keuangan warga negaranya, PISA (2012). Menurut Atkinson dan Messy (2012), pemerintah di seluruh dunia tertarik menemukan pendekatan yang efektif untuk meningkatkan tingkat literasi keuangan masyarakat mereka melalui penciptaan atau perbaikan strategi nasional untuk pendidikan keuangan dengan 
tujuan menawarkan kesempatan belajar di berbagai tingkat pendidikan. OJK (2016) juga menjelaskan bahwa para pemimpin negara-negara yang tergabung dalam G20 melalui forum Organisation for Economic Cooperation and Development (OECD) pada tahun 2010 juga telah menetapkan bahwa integrasi dari prinsip literasi keuangan, inklusi keuangan, dan perlindungan konsumen sangat penting untuk memperkuat sistem keuangan dan meningkatkan kesejahteraan masyarakat.

Sebagai negara berkembang yang memiliki wilayah sangat luas dan penduduk nomor empat terbesar di dunia, Indonesia menghadapi masalah banyaknya penduduk yang belum memahami masalah keuangan. Dengan kata lain, tingkat literasi keuangan di Indonesia berada dalam tingkat yang rendah dibandingkan dengan negara lain. Bukti nyata dari rendahnya literasi keuangan ditunjukkan oleh masih sedikitnya masyarakat yang bersentuhan dengan lembaga keuangan maupun produk keuangan (OJK, 2016).

Survei Nasional Literasi dan Inklusi Keuangan (SNLIK) kedua yang dilakukan Otoritas Jasa Keuangan (OJK) pada tahun 2016 menunjukkan indeks literasi keuangan sebesar 29,66\% dan indeks inklusi keuangan sebesar 67,82\%. Angka tersebut meningkat dibanding hasil SNLIK pada 2013, yaitu indeks literasi keuangan $21,84 \%$ dan indeks inklusi keuangan 59,74\%. Dengan demikian, telah terjadi peningkatan pemahaman keuangan (well literate) dari 21,84 persen menjadi 29,66\%, serta peningkatan akses terhadap produk dan layanan jasa keuangan (inklusi keuangan) dari 59,74\% menjadi 67,82\%. Namun hal tersebut harus ditingkatkan lagi mengingat angka harapan yang dicanangkan pemerintah melalui Peraturan Presiden Republik Indonesia Nomor 82 tahun 2016 tentang Strategi Nasional Keuangan Inklusif (SNKI) sebesar 75\% pada tahun 2019 dapat tercapai. Literasi keuangan pada lembaga keuangan tergolong masih rendah terutama pada lembaga pasar modal dan lembaga dana pensiun. Hal ini menunjukkan sedikitnya masyarakat yang mengerti tentang investasi dan melakukan investasi, serta perencanaan keuangan untuk masa depan terutama saat mereka telah berhenti bekerja dan sudah tidak memiliki pendapatan setiap bulannya.

Literasi keuangan diartikan sebagai kemampuan individu untuk mengambil keputusan dalam hal pengaturan keuangan pribadinya. Individu harus memiliki suatu pengetahuan dan keterampilan untuk mengelola sumber keuangan pribadinya secara efektif demi kesejahteraannya. Selain menetapkan keputusan keuangan jangka pendek seperti tabungan dan pinjaman, individu juga harus memikirkan keputusan keuangan jangka panjang seperti perencanaan pensiun dan perencanaan pendidikan untuk anak-anaknya.

Rendahnya literasi keuangan dan keterlibatan pada inklusi keuangan menyebabkan masyarakat mudah tergiur oleh investasi yang merugikan dengan iming-iming keuntungan yang sangat tinggi. Oleh karena itu, masyarakat diharapkan untuk memiliki pemahaman tentang pengetahuan dan pengelolaan keuangan. Selain itu, masyarakat harus mampu mengelola uang dan mengetahui konsekuensi yang ditimbulkan dari setiap transaksi menggunakan uang (OJK, 2016). Hal tersebut seperti tertera pada Tabel 1 . berikut. 
Tabel 1. Literasi dan Inklusi Keuangan - Sektoral di Indonesia

\begin{tabular}{clcc}
\hline No. & Produk Keuangan & Literasi Keuangan & Inklusi Keuangan \\
\hline 1. & Perbankan & $28.94 \%$ & $63.63 \%$ \\
2. & Perasuransian & $15.76 \%$ & $12.08 \%$ \\
3. & Dana Pensiun & $10.91 \%$ & $4.66 \%$ \\
4. & Lembaga Pembiayaan & $13.05 \%$ & $11.85 \%$ \\
5. & Pergadaian & $17.82 \%$ & $10.49 \%$ \\
6. & Pasar Modal & $4.40 \%$ & $1.25 \%$ \\
\hline
\end{tabular}

Sumber: OJK, 2016

Krishna, Rofaida, dan Sari (2010) menjelaskan bahwa literasi keuangan membantu individu agar terhindar dari masalah keuangan. Kesulitan keuangan bukan hanya fungsi dari pendapatan semata (rendahnya pendapatan), tetapi juga dapat muncul jika terjadi kesalahan dalam pengelolaan keuangan (miss management) seperti kesalahan penggunaan kredit, dan tidak adanya perencanaan keuangan. Keterbatasan finansial dapat menyebabkan perasaan tertekan dan rendahnya kepercayaan diri. Adanya pengetahuan keuangan dan literasi keuangan akan membantu individu dalam mengatur perencanaan keuangan pribadi, sehingga individu tersebut bisa memaksimalkan nilai waktu uang dan keuntungan yang diperoleh oleh individu akan semakin besar yang kemudian akan meningkatkan taraf kehidupannya. Semakin kompleksnya kebutuhan individual yang juga disertai semakin kompleksnya produk-produk finansial yang kemudian menjadi alasan utama (pendorong) bagi masyakat untuk memiliki literasi keuangan yang memadai. Pada bagian kebutuhan individu dapat dilihat bahwa stabilitas dunia kerja semakin menurun, dan tingkat pengangguran semakin tinggi karena lapangan pekerjaan tidak bertumbuh seiring dengan pertumbuhan tenaga kerja. Jaminan sosial dari pemerintah juga semakin rendah, yang mengakibatkan tanggung jawab pribadi semakin besar. Kemiskinan, hutang, dan jumlah orang yang berwirausaha juga semakin meningkat. Sementara itu, pola distribusi yang baru, deregulasi di pasar keuangan, semakin luas dan beragamnya cakupan produk-produk finansial juga turut meningkatkan kompleksitas produk-produk keuangan (Nababan \& Sadalia, 2012).

Menurut Lusardi et al., (2010), generasi muda tidak hanya akan menghadapi kompleksitas yang semakin meningkat dalam produk-produk keuangan, jasa, dan pasar, tetapi mereka lebih cenderung harus menanggung risiko keuangan di masa depan yang lebih dari orang tua mereka. Fenomena yang terjadi saat ini masih belum sesuai dengan harapan karena kejadian besar pasak dari pada tiang masih banyak terjadi. Banyak siswa yang tidak menyadari bahwa uang yang dimilikinya telah habis sebelum pada waktunya, mereka sendiri tidak menyadari uang tersebut digunakan untuk keperluan apa. Hal ini bukan berarti uang yang dimiliknya kurang, tetapi hal ini terjadi karena kesalahan pengalokasian uang tersebut. Siswa cenderung mengalokasikan uang tersebut untuk apa yang mereka inginkan, bukan apa yang mereka butuhkan. Maka dari itu, siswa perlu diajarkan cara pengelolaan keuangan yang benar sehingga mahasiswa dapat memanfaatkan dengan maksimal uang yang dimilikinya.

Kesalahan dalam pengelolaan keuangan (miss management) juga dapat diakibatkan oleh perilaku konsumtif. Amaliya (2015) menyatakan beberapa penyebab siswa berperilaku konsumtif diantaranya adalah kemajuan teknologi yang 
memudahkan siswa melakukan belanja secara online melalui media sosial dan adanya perubahan lingkungan. Penyebab lain yaitu dikarenakan di sekolah, siswa bertemu dengan siswa lain yang memiliki tingkat ekonomi lebih tinggi, pergaulan dan pola pikir yang baru, style yang semakin berkembang, pengetahuan teknologi dan informasi yang lebih maju, dan adanya uang saku yang diberikan oleh orang tuanya, dan lengkapnya fasilitas yang mereka miliki dangunakan, misalnya mobil atau kendaraan, smartphone, dan gadget lainnya.

Berbagai survei atau penelitian telah dilakukan untuk mengetahui tingkat literasi keuangan masyarakat Indonesia. Salah satunya yaitu penelitian literasi keuangan oleh Master Card terhadap enam belas negara Asia Pasifik yang dirilis pada Juni 2016 menunjukkan bahwa tingkat literasi masyarakat Indonesia berada di urutan empat belas dengan skor indeks literasi sebesar 60\%. Indonesia tertinggal dengan negara tetangga seperti Singapura, Malaysia dan Thailand. Hal ini menjelaskan bahwa pengetahuan masyarakat Indonesia, termasuk kemampuan mengelola uang dan mengetahui konsekuensi yang ditimbulkan dari setiap transaksi menggunakan uang berada di bawah negara-negara berkembang lain di ASEAN seperti Malaysia dan Thailand. Tidak berbeda jauh dengan Indonesia, penelitian Master Card menunjukkan bahwa masyarakat Vietnam memiliki tingkat literasi keuangan sebesar 63\%. Jika dilihat dari aspek Manajemen Keuangan Dasar, penduduk Vietnam dan Indonesia memiliki skor hampir sama yaitu 57 dan 56 (mastercard.com).

Rendahnya literasi keuangan siswa Vietnam juga dibuktikan melalui survey yang dilakukan oleh Department of Education and Training of Ho Chi Minh City, kepada 7 sekolah di Vietnam tahun 2012 dan 2013 pada aspek money management usia 13 sampai 18 tahun. Hasil yang diperoleh adalah 17,2 \% siswa menyisihkan sebagian besar uangnya untuk menabung, 8,8\% menghabiskan sebagian besar uangnya untuk keinginan, dan $12 \%$ tidak mengetahui untuk apa saja uang yang mereka telah habiskan. Artinya, banyak dari mereka memiliki literasi keuangan yang buruk karena manajemen keuangan yang buruk juga.

Keown (2011) melakukan penelitian berjudul "The Financial Knowledge of Canadians". Penelitian ini bertujuan untuk mengetahui pengaruh jenis kelamin, kepemilikan rumah, tempat tinggal, status keluarga dan usia terhadap pendidikan dan pengetahuan keuangan di Kanada. Hasil penelitian menunjukkan bahwa jenis kelamin, kepemilikan rumah, tempat tinggal, status keluarga dan usia berpengaruh terhadap pendidikan dan pengetahuan keuangan.

Taft, Hosein, dan Mehrizi (2013) menemukan terdapat hubungan positif antara usia dengan literasi keuangan dan financial well-being. Shaari, Hasan, Mohamed dan Sabri (2013) dalam penelitiannya yang dilakukan pada mahasiswa di Malaysia dengan sampel sebanyak 384, menemukan bahwa terdapat hubungan negatif antara literasi keuangan mahasiswa dengan usia. Ansong dan Gyensare (2012) menemukan bahwa usia memiliki hubungan dengan literasi keuangan pada mahasiswa. Perilaku konsumtif dan hedonisme telah melekat pada kehidupan manusia, karena hidup dalam dunia konsumerisme tidak pandang umur, jenis kelamin ataupun status sosial. Pola hidup konsumtif sering dijumpai di kalangan generasimuda, yang orientasinya diarahkan kenikmatan, kesenangan, serta kepuasan dalam mengkonsumsi barang secara berlebihan.

Chen dan Volpe (1998) menemukan tingkat literasi keuangan yang rendah pada peserta yang berusia 18-22 tahun. Alasan untuk rendahnya tingkat pengetahuan dapat dikaitkan dengan usia muda 18 sampai 22 tahun dari peserta atau di bawah 30 
tahun sebagai mayoritas dari mereka berada dalam tahap yang sangat awal siklus dari hidup finansial mereka. Saat tahap siklus ini, mereka memiliki sejumlah masalah keuangan yang berkaitan dengan pengetahuan umum tentang keuangan, tabungan dan pinjaman, dan asuransi. Saat periode ini, sebagian besar pendapatan mereka dibelanjakan konsumsi daripada investasi. Sedangkan dalam proses mengatur keuangan, generasi ini kerap melakukan kesalahan yang sama.

Cameron et al., (2013) melakukan penelitian untuk mengetahui dan membandingkan tingkat literasi keuangan siswa sekolah tinggi di tiga negara, yaitu New Zealand, Jepang dan USA melalui Financial Fitness for Life - High School (FFFL-HS) test. Hasil tes menunjukkan siswa di New Zealand dan USA memiliki tingkat literasi keuangan yang hampir sama dengan skor 45,3 dan 44,8 dan berada di bawah Jepang dengan skor 56,7. Kesemuanya menunjukkan literasi keuangan yang rendah apabila mengacu pada pengategorian literasi keuangan.

Chen dan Volpe (1998) mengkategorikan tingkat literasi keuangan menjadi tiga kelompok, yaitu: 1) $<60 \%$, yang berarti individu memiliki pengetahuan tentang keuangan yang rendah, 2) $60 \%-79 \%$, yang berarti individu memiliki pengetahuan tentang keuangan yang sedang, dan 3) $>80 \%$ yang menunjukkan bahwa individu memiliki pengetahuan keuangan yang tinggi. Pengategorian ini didasarkan pada presentase jawaban responden yang benar dari sejumlah pertanyaan yang digunakan untuk mengukur literasi keuangan.

Banyak siswa yang belum memiliki tingkat literasi keuangan tinggi dengan didasarkan pada dimensi penerapan (application dimension). Terkait rendahnya tingkat literasi keuangan siswa sekolah menengah di Indonesia, terdapat indikasi bahwa pendidikan finansial belum diterapkan pada mata pelajaran ekonomi di sekolah. Sedangkan di Vietnam, berdasarkan overview yang diterbitkan oleh State Bank of Vietnam, menunjukkan bahwa Vietnam membutuhkan kurikulum pendidikan keuangan yang menyeluruh karena belum adanya program dan kebijakan pendidikan keuangan di sekolah. Oleh karena itu, kedua negara sama-sama merencanakan penerapan kurikulum pendidikan keuangan di sekolah dalam waktu dekat secara menyeluruh.

Penelitian ini merupakan kombinasi penelitian Margaretha dan Pambudhi (2015), Homan, Hery Syaerul (2015) dan Sabri et al., (2012). Margaretha dan Pambudhi (2015) mengembangkan faktor-faktor yang mempengaruhi literasi keuangan untuk mengukur tingkat literasi keuangan mahasiswa, dengan variabel independen jenis kelamin, usia, IPK dan pendapatan orang tua. Homan, Hery Syahrul (2015) dalam penelitian berjudul Comparative Study of Student Financial Literacy and Its Demographic Factors berisi tentang perbandingan literasi keuangan dan faktor-faktor demografi berupa jenis kelamin, tempat tinggal, pendapatan dan pendidikan orang tua antara mahasiswa semester awal dan semester akhir pada STIE Ekuitas Bandung. Sabri et al., (2018) melalui penelitiannya terhadap mahasiswa di Malaysia menggabungkan pengaruh latar belakang keluarga dan pribadi, faktor akademis, dan pengalaman konsumsi saat masa kecil terhadap literasi keuangan mahasiswa. Sedangkan dalam penelitian ini, penulis menggunakan metode komparasi literasi keuangan dan faktor yang mempengaruhinya pada siswa di dua sekolah menengah yang berbeda negara. Sebagian besar hasil penelitian terdahulu mengungkapkan pengaruh variabel-variabel independen terhadap variabel dependen namun belum ada yang meneliti tentang komparasi dua sekolah menengah pada dua negara berbeda. Pada penelitian ini mengkaji kebenaran variabel independen (jenis 
kelamin, pendidikan dan pendapatan orang tua) dalam mempengaruhi literasi keuangan melalui metode komparasi dua sekolah berbeda negara.

Literasi keuangan merupakan kemampuan seorang untuk mengambil keputusan dalam hal pengaturan keuangan pribadinya. Menurut Potrich et al., (2016), literasi keuangan dipahami sebagai penguasaan seperangkat pengetahuan, sikap dan perilaku, telah diasumsikan peran mendasar kemungkinan orang untuk membuat keputusan yang bertanggung jawab karena mereka berusaha untuk mencapai kesejahteraan finansial. Literasi keuangan mengacu pada pengetahuan dan keterampilan yang diperlukan untuk menangani tantangan keuangan dan keputusan dalam kehidupan sehari-hari (Shon et al., 2012).

Loke (2015) dalam penelitiannya mendefinisikan literasi keuangan sebagai kemampuan dan pengetahuan untuk melaksanakan pengambilan keputusan keuangan yang efektif. Secara khusus, literasi keuangan mengacu pada pengetahuan dan keterampilan yang diperlukan untuk menangani tantangan keuangan dan keputusan dalam kehidupan sehari-hari (Sohn et al., 2012). Huston (2010) menyatakan literasi keuangan memiliki aplikasi tambahan dimensi yang menyiratkan bahwa seorang individu harus memiliki kemampuan dan kepercayaan diri menggunakan pengetahuan keuangannya untuk membuat keputusan keuangan.

Literasi keuangan seseorang dipengaruhi oleh beberapa faktor. Ansong dan Gyensare (2012), menemukan bahwa literasi keuangan dipengaruhi beberapa faktor yaitu: 1) Usia, 2) Pengalaman bekerja, 3) Pendidikan ibu, 4) Jurusan. Margaretha dan Pambudhi (2015) menemukan adanya pengaruh faktor 1) Jenis kelamin, 2) IPK, 3) Pendapatan orang tua terhadap tingkat literasi keuangan. Shaari, Hasan, Mohamed, dan Sabri (2013), menyatakan bahwa 1) Usia, 2) Spending habit, 3) Jenis kelamin, 4) Fakultas, 5) Tahun masuk kuliah berpengaruh terhadap literasi keuangan. Nababan dan Sadalia (2012) menemukan adanya pengaruh antara faktor 1) Jenis kelamin, 2) Stambuk (tahun masuk sekolah/angkatan), 3) Tempat tinggal 4) IPK berpengaruh terhadap literasi keuangan.

Menurut OJK, faktor-faktor yang mempengaruhi tingkat literasi keuangan, yaitu: 1) Jenis kelamin 2) Tingkat pendidikan 3) Tingkat pendapatan (Otoritas Jasa Keuangan, 2014). Menurut Widayati (2012) faktor-faktor yang mempengaruhi tingkat literasi keuangan yaitu: 1) Status sosial ekonomi orang tua 2) Pendidikan pengelolaan keuangan keluarga 3) Pembelajaran keuangan di perguruan tinggi negeri. Menurut Rita dan Pesudo (2013) menyebutkan faktor 1) Jenis kelamin 2) Fakultas 3) Indeks Prestasi Kumulatif, merupakan faktor-faktor yang mempengaruhi literasi keuangan. Sedangkan Lusardi, Mitchell, dan Curto (2010) menemukan bahwa jenis kelamin, pendidikan dan pendidikan dari orang tua mempengaruhi literasi keuangan.

Berdasarkan latar belakang tersebut, peneliti tertarik untuk memetakan determinan rendahnya tingkat literasi keuangan siswa sekolah menengah di Indonesia dan Vietnam dengan judul Determinan Tingkat Literasi Keuangan Siswa di Sekolah Menengah (Studi Komparatif: Indonesia dan Vietnam).

\section{METODE}

Jenis penelitian ini adalah penelitian ex post facto dengan pendekatan kuantitatif. Sugiyono (2014) menjabarkan bahwa penelitian ex post facto meneliti peristiwa yang telah terjadi dan meruntut ke belakang untuk mengetahui faktor-faktor yang dapat menyebabkan timbulnya kejadian tersebut. Sedangkan penelitian kuantitatif dapat diartikan sebagai metode penelitian yang berlandaskan filsafat positivisme yang 
digunakan untuk meneliti populasi atau sampel tertentu dengan teknik pengambilan sampel pada umumnya dilakukan secara random, pengumpulan data menggunakan instrumen penelitian, analisis data bersifat kuantitatif atau statistik dengan tujuan untuk menguji hipotesis yang telah ditetapkan (Sugiyono, 2014).

Berdasarkan tingkat eksplanasi (level of explanation), desain penelitian ini adalah desain asosiatif dan komparatif. Menurut Sugiyono (2014), penelitian asosiatif adalah penelitian yang menanyakan hubungan antara dua variabel atau lebih. Adapun penelitian ini merupakan penelitian komparatif. Sugiyono (2014) menyatakan bahwa penelitian asosiatif hubungan kausal adalah hubungan yang bersifat sebab akibat sehingga terdapat variabel independen dan dependen. Penelitian ini menanyakan pengaruh jenis kelamin, pendidikan orang tua dan pendapatan orang tua terhadap literasi keuangan siswa sekolah menengah di Indonesia dan Vietnam. Setelah diketahui besarnya pengaruh variabel-variabel independen terhadap variabel dependen, kemudian dilakukan komparasi antara kedua variabel dependen.

Penelitian ini akan mendeskripsikan hasil uji statistik dan menguji hipotesis mengenai faktor-faktor yang mempengaruhi tingkat literasi keuangan siswa sekolah menengah. Metode penelitian yang digunakan dalam penelitian ini adalah metode survei. Menurut Sanusi (2014), cara survei merupakan cara pengumpulan data di mana peneliti atau pengumpul data mengajukan pertanyaan atau pernyataan kepada responden baik dalam bentuk lisan maupun secara tertulis. Penelitian ini menggunakan metode penyebaran kuesioner untuk mengetahui identitas dan disisipi pertanyaan yang berkaitan dengan faktor-faktor penentu tingkat literasi keuangan. Kemudian dilakukan uji Mann-Whitney untuk melakukan perbandingan hasil pengaruh variabel-variabel independen (jenis kelamin, pendidikan orang tua dan pendapatan orang tua) terhadap variabel dependen (literasi keuangan).

Kuesioner dalam penelitian ini berbentuk tertutup yaitu sudah disediakan jawabannya sehingga responden hanya memilih. Responden dapat memilih alternatif jawaban yang tersedia yaitu melalui skema 12 soal pilihan ganda, 5 soal benar (B) dan salah (S) dan 8 pernyataan sangat setuju/sangat penting hingga sangat tidak setuju/sangat tidak penting berskala 5 hingga 1 .

\section{HASIL DAN DISKUSI}

Objek penelitian ini yaitu siswa SMA Hidayatullah, Semarang dan Truong Trung Hoc Pho Thông (THPT) Tran Nhan Tong. SMA Hidayatullah merupakan salah satu sekolah swasta berakreditasi A di Semarang. Sekolah tersebut memiliki gedung tiga lantai dan fasilitas yang memadai. Tidak berbeda dengan THPT. Tran Nhan Tong yang merupakan salah satu sekolah swasta yang terletak di distrik Binh Tan, Kota Ho Chi Minh. Sekolah tersebut memiliki gedung tiga lantai dan fasilitas pendidikan yang memadai. Jumlah populasi masing-masing sebanyak 131 dan 123 siswa yang kemudian diambil sampel jenuh. Jumlah sampel pada penelitian ini sama dengan jumlah populasi yaitu total 254 responden.

Berdasarkan uji deskriptif, pendapatan orangtua SMA Hidayatullah perbulan, sebanyak 2 orang memiliki pendapatan perbulan sebesar $<R p .1 .000 .000,00,28$ orang atau 22,3 persen memiliki pendapatan perbulan sebesar Rp.1.000.000,00 Rp.3.000.000,00, sebanyak 42 orang atau 35,0 persen memiliki pendapatan sebesar > Rp.3.000.000,00 - Rp.5.000.000,00, sebanyak 25 orang atau 21,0 persen memiliki pendapatn perbulan sebesar > Rp.5.000.000,00 - Rp.7.000.000,00 dan 24 orang atau 
20,0 persen memiliki pendapatan sebanyak > Rp.7.000.000,00. Dengan demikian pendapatan $>$ Rp. 3.000.000,00 - Rp. 5.000.000,00 perbulan paling banyak dimiliki oleh orangtua SMA Hidayatullah yaitu sebanyak 42 orang atau 35,0 persen. Sedangkan pendapatan orangtua siswa THPT Tran Nhan Tong perbulan, sebanyak 4 orang memiliki pendapatan perbulan sebesar < Rp.1.000.000,00, 67 orang atau 56,8 persen memiliki pendapatan perbulan sebesar Rp.1.000.000,00 - Rp.3.000.000,00, sebanyak 39 orang atau 33,1 persen memiliki pendapatan sebesar $>$ Rp.3.000.000,00 Rp.5.000.000,00, sebanyak 8 orang atau 6,8 persen memiliki pendapatn perbulan sebesar >Rp.5.000.000,00 - Rp.7.000.000,00 dan 24 orang atau 20,0 persen memiliki pendapatan sebanyak >Rp.7.000.000,00. Dengan demikian pendapatan >Rp. 3.000.000,00 - Rp. 5.000.000,00 perbulan paling banyak dimiliki oleh orangtua SMA Hidayatullah yaitu sebanyak 42 orang atau 35,0 persen.

\section{Analisis Statistik Deskriptif}

Analisis deskriptif dalam penelitian ini digunakan untuk memberikan gambaran penyebaran hasil penelitian masing-masing variabel tanpa adanya uji signifikansi dan tanpa ada taraf kesalahan. Hal ini dikarenakan dalam analisis deskriptif, peneliti tidak bermaksud membuat generalisasi, sehingga tidak ada kesalahan generalisasi. Literasi keuangan kognitif siswa SMA Hidayatullah dikelompokkan menjadi dua, yaitu siswa berkategori literasi sedang sebanyak 108 siswa $(82,4 \%)$ dan kategori literasi tinggi sebanyak 23 siswa $(17,6 \%)$ dari total keseluruhan jumlah siswa sebanyak 131 siswa. Sedangkan, literasi keuangan kognitif siswa THPT. Tran Nhan Tong dikelompokkan menjadi dua, yaitu siswa berkategori literasi sedang sebanyak 104 siswa $(84,5 \%)$ dan kategori literasi tinggi sebanyak 19 siswa $(15,4 \%)$ dari total keseluruhan jumlah siswa sebanyak 123 siswa. Sedangkan literasi keuangan afektif siswa SMA Hidayatullah dikelompokkan menjadi tiga, yaitu siswa berkategori literasi sedang sebanyak 112 siswa (85,5\%), kategori literasi tinggi sebanyak 16 siswa $(12,2 \%)$ dan literasi sangat tinggi sebanyak 3 siswa $(2,3 \%)$ dari total keseluruhan jumlah siswa sebanyak 131 siswa. Sedangkan, literasi keuangan afektif siswa THPT. Tran Nhan Tong juga dikelompokkan menjadi tiga, yaitu siswa berkategori literasi sedang sebanyak 104 siswa (84,5\%), kategori literasi tinggi sebanyak 15 siswa (12,2\%) dan literasi sangat tinggi sebanyak 4 siswa $(3,3 \%)$ dari total keseluruhan jumlah siswa sebanyak 123 siswa.

Pada literasi keuangan kognitif, siswa SMA Hidayatullah dan THPT dan Tran Nhan Tong berdasarkan jenis kelamin dikelompokkan menjadi dua, yaitu siswa berkategori literasi sedang sebanyak 110 siswa (94\%) dan kategori literasi tinggi sebanyak 7 siswa (6\%) dari total keseluruhan jumlah siswa laki-laki sebanyak 117 siswa. Sedangkan, literasi keuangan kognitif siswa perempuan SMA Hidayatullah dan THPT. Tran Nhan Tong dikelompokkan menjadi dua, yaitu siswa berkategori literasi sedang sebanyak 102 siswa $(74,5 \%)$ dan kategori literasi tinggi sebanyak 35 siswa $(25,5 \%)$ dari total keseluruhan jumlah siswa perempuan sebanyak 137 siswa.

Selanjutnya, literasi keuangan afektif siswa SMA Hidayatullah dan THPT. Tran Nhan Tong berdasarkan jenis kelamin masing-masing dikelompokkan menjadi tiga. Siswa laki-laki berkategori literasi sedang sebanyak 110 siswa (94\%), kategori literasi tinggi sebanyak 5 siswa $(4,3 \%)$ dan literasi sangat tinggi sebanyak 2 siswa $(1,7 \%)$ dari total keseluruhan jumlah siswa laki-laki sebanyak 117 siswa. Sedangkan, literasi keuangan afektif siswa perempuan juga dikelompokkan menjadi tiga, yaitu siswa perempuan berkategori literasi sedang sebanyak 102 siswa (74,5\%), kategori 
literasi tinggi sebanyak 28 siswa $(20,4 \%)$ dan literasi sangat tinggi sebanyak 7 siswa $(5,1 \%)$ dari total keseluruhan jumlah siswa perempuan sebanyak 137 siswa.

\section{Uji Hipotesis}

Pengujian hipotesis dilakukan untuk mengetahui keakuratan dari masing-masing hipotesis penelitian terhadap kenyataan dari data yang diperoleh oleh penulis. Uji hipotesis perlu dilakukan dalam penelitian kuantitatif. Data yang diperoleh oleh penulis selanjutnya akan di uji menggunakan uji statistik. Apabila data terdistribusi secara normal maka digunakan uji statistic parametrik sebaliknya jika data tidak terdistribusi secara normal maka akan digunakan uji statistik non-parametrik. Pada uji normalitas menggunakan metode Kolmogorov-Smirnov diketahui bahwa data tidak terdistribusi secara normal sehingga uji hipotesis akan dilakukan menggunakan uji statistik non-parametrik yaitu uji Mann-Whitney. Uji Mann-Whitney digunakan untuk menguji hipotesis komparatif dua sampel bebas jika datanya berbentuk ordinal. Uji Mann-Whitney dilakukan dengan menggunakan bantuan aplikasi SPSS 21. Dasar pengambilan keputusan dilakukan dengan membandingkan angka probabilitas dengan ketentuan. Berikut hasil uji Mann-Whitney disajikan dalam Tabel 2.

Tabel 2. Hasil Uji Mann-Whitney per Variabel

\begin{tabular}{lcccc}
\hline \multicolumn{1}{c}{ Mean Rank } & & \\
\hline \multicolumn{1}{c}{ Variabel } & Hid & TNT & Asymp. Sig. & Keterangan \\
\hline Kognitif & 128,18 & 112,8 & 0,081 & Tidak Berbeda \\
Afektif & 110,97 & 130,0 & 0,33 & Tidak Berbeda \\
Gender & & & 0,000 & Berbeda \\
Edu & & & 0,001 & Berbeda \\
Income & & & 0,489 & Tidak Berbeda \\
\hline
\end{tabular}

Sumber: Hasil Olah Data, 2020

Berdasarkan Tabel 2, dapat dijelaskan bahwa literasi kognitif SMA Hidayatullah dibanding THPT Tran Nhan Tong memiliki nilai signifanksi sebesar 0,081 > 0,05 ini berarti bahwa untuk literasi kognitif kedua sekolah secara signifikan tidak ada perbedaan. Sedangkan untuk nilai Mean Rank literasi kognitif SMA Hidayatullah sebesar 128,18 dan THPT Tran Nhan Tong sebesar 112,82 ini berarti tingkat pengetahuan siswa SMA Hidayatullah lebih tinggi jika dibandingkan dengan THPT Tran Nhan Tong.

Untuk perbandingan variabel literasi afektif SMA Hidayatullah dibanding THPT Tran Nhan Tong, nilai signifikansi sebesar 0,33>0,05, ini berarti literasi afektif antara siswa SMA Hidayatullah dan THPT Tran Nhan Tong tidak terdapat perbedaan. Perbandingan nilai Mean Rank variabel literasi afektif antara siswa SMA Hidayatullah dan THPT Tran Nhan Tong berturut-turut adalah 110,97 dan 130,03, ini berarti bahwa pemahaman siswa THPT Tran Nhan Tong tentang literasi keuangan lebih unggul dibandingkan dengan SMA Hidayatullah.

Hasil pengujian terhadap variabel jenis kelamin diperoleh nilai signifikansi sebesar 0,000. Nilai signifikansi tersebut lebih kecil dari 0,05, sehingga dapat disimpulkan bahwa terdapat perbedaan pengaruh jenis kelamin terhadap tingkat literasi keuangan di kalangan siswa SMA Hidayatullah dan THPT Tran Nhan Tong. 
Hasil pengujian terhadap variabel pendidikan orangtua diperoleh nilai signifikansi sebesar 0,001. Nilai signifikansi tersebut lebih kecil dari 0,05, sehingga dapat disimpulkan bahwa terdapat perbedaan pengaruh pendidikan orangtua terhadap tingkat literasi keuangan di kalangan siswa SMA Hidayatullah dan THPT Tran Nhan Tong.

Hasil pengujian terhadap variabel pendapatan orangtua diperoleh nilai signifikansi sebesar 0,489. Nilai signifikansi tersebut lebih besar dari 0,05, sehingga dapat disimpulkan bahwa tidak terdapat perbedaan pengaruh pendapatan orangtua terhadap tingkat literasi keuangan di kalangan siswa SMA Hidayatullah dan THPT Tran Nhan Tong.

Penelitian ini merupakan studi mengenai tingkat literasi keuangan di kalangan siswa Indonesia dan Vietnam. Kegiatan pengukuran tingkat literasi keuangan tingkat literasi mengandung informasi tentang jenis kelamin, pendidikan orangtua, dan pendapatan orangtua. Hasil pengujian yang telah dilakukan oleh peneliti adalah sebagai berikut:

\section{Pengaruh Jenis Kelamin terhadap Tingkat Literasi Keuangan di Kalangan Siswa Indonesia dan Vietnam}

Jenis kelamin adalah perbedaan biologis dan fisiologis yang dapat membedakan lakilaki dan perempuan (Ariadi dkk, 2015). Jenis kelamin adalah suatu konsep biologis dan fisiologis yang membedakan antara laki-laki dan perempuan yang tidak dapat ditukar karena keadaan alamiah manusia yang sudah melekat pada diri manusia sejak lahir. Perempuan dan laki-laki memiliki kondisi-kondisi khusus yang berbeda, baik dari segi fisik biologis, maupun dari segi psikologisnya. Perbedaan tersebut merupakan sumber dari perbedaan fungsi dan peran yang diemban oleh wanita dan pria. Jika memperhatikan perbedaan peran dan fungsi yang diemban wanita dan pria, maka akan terlihat bahwa pergerakan atau perjalanan yang dilakukan oleh wanita memiliki pola yang berbeda dengan pergerakan atau perjalanan yang dilakukan oleh pria (Amaliyah dan Witiastuti, 2015).

Penelitian Krishna et al., (2010), Nababan dan Sadalia (2015), dan Margaretha dan Pambudhi (2015) menyatakan bahwa jenis kelamin mempengaruhi literasi keuangan. Laki-laki tidak banyak mempertimbangkan variabel-variabel yang berhubungan dengan keputusan investasinya, karena karakter laki-laki berbanding terbalik dengan perempuan yaitu sangat mandiri, tidak terlalu emosional, sangat logis, mudah membuat keputusan, sangat percaya diri, dan tidak terlalu membutuhkan rasa aman. Perempuan cenderung lebih berhati-hati dalam membuat keputusan keuangan.

Karakteristik memang menyebabkan adanya perbedaan tingkat literasi keuangan pada perempuan dan laki-laki. Sifat perempuan yang lebih berhati-hati dalam membuat keputusan tentang investasi menyebabkan perempuan akan mempelajari banyak hal mengenai konsep keuangan untuk membuat keputusan yang benar. Kondisi ini menyebabkan tingkat pengetahuan perempuan lebih tinggi dibandingkan laki-laki, dengan tingkat pengetahuan yang tinggi maka tingkat pemahaman mereka pun akan lebih mendalam. Oleh karena itu responden perempuan akan lebih berusaha mempelajari banyak konsep keuangan sehingga tingkat literasi keuangan mereka cenderung tinggi. Berdasarkan penyataan di atas, maka dapat lihat wajar jika tingkat pengetahuan dan pemahaman perempuan lebih tinggi dibandingkan dengan laki-laki sehingga faktor jenis kelamin dapat mempengaruhi tingkat literasi keuangan seseorang. 
Berdasarkan hasil pengujian statistik deskriptif menunjukkan bahwa perempuan memiliki tingkat literasi keuangan yang lebih tinggi. Sedangkan pada hasil uji Mann-Whitney menunjukkan bahwa bahwa terdapat perbedaan pengaruh jenis kelamin terhadap tingkat literasi keuangan di kalangan siswa SMA Hidayatullah dan THPT Tran Nhan Tong karena diperoleh nilai asymp. sig. sebesar $0,000<0,005$, yang artinya terdapat perbedaan pengaruh jenis kelamin terhadap literasi keuangan, sehingga hipotesis pertama diterima. Penelitian ini menemukan adanya perbedaan tingkat literasi keungan berdasarkan jenis kelamin.

\section{Pengaruh Pendidikan Orangtua terhadap Tingkat Literasi Keuangan di Kalangan Siswa Indonesia dan Vietnam}

Menurut Nababan dan Sadalia (2012), tingkat pendidikan orang tua adalah jenjang pendidikan terakhir yang ditempuh oleh orang tua responden. Tingkat pendidikan orang tua adalah modal untuk merawat dan memperhatikan akan kebutuhan anak, diharapkan semakin tinggi pendidikan orang tuanya maka akan semakin banyak pengetahuan yang berguna dalam merawat anaknya (Saputro dan Nurhayati, 2014).

Lusardi et al., (2010) menemukan bahwa pendidikan orang tua merupakan prediktor yang besar untuk literasi keuangan anak. Ansong dan Gyensare (2012) menjelaskan bahwa pendidikan ibu berhubungan dengan literasi keuangan anak. Menurut Santrock (2007) orang tua dengan tingkat pendidikan yang lebih tinggi akan lebih mungkin percaya bahwa keterlibatan mereka dalam pendidikan anak adalah penting. Mereka lebih mungkin untuk berpartisipasi dalam pendidikan anak dan memberi stimuli intelektual di rumah.

Hasil uji Mann Whitney menunjukkan bahwa bahwa terdapat perbedaan pengaruh pendidikan orangtua terhadap tingkat literasi keuangan di kalangan siswa SMA Hidayatullah dan THPT Tran Nhan Tong yang ditunjukkan oleh nilai asymp. sig. sebesar 0,001<0,005 sehingga terdapat perbedaan pengaruh faktor pendidikan orang tua terhadap literasi keuangan sehingga hipotesis kedua diterima.

Hasil penelitian ini didukung dengan penelitian yang dilakukan oleh Ansong dan Gyensare (2012) dan Lusardi et al., (2010) yang menemukan adanya pengaruh positif antara pendidikan orangtua dengan tingkat literasi keuangan anak. Penelitian mereka juga menjelaskan bahwa semakin tinggi pendidikan orangtua, maka anak akan semakin baik dalam mengelola keuangan. Hal ini mengindikasikan bahwa siswa yang memiliki orangtua berpendidikan tinggi akan cenderung berpengetahuan luas mengenai konsep keuangan sehingga mereka memiliki tingkat literasi keuangan yang tinggi pula.

\section{Pengaruh Pendapatan Orangtua terhadap Tingkat Literasi Keuangan di Kalangan Siswa Indonesia dan Vietnam}

Menurut Nababan dan Sadalia (2012), pendapatan orang tua adalah tingkat penghasilan yang diperoleh orang tua responden selama sebulan baik dari penerimaan gaji, upah, ataupun penerimaan dari hasil usaha. Pendapatan merupakan salah satu indikator untuk mengukur kesejahteraan seseorang atau masyarakat, sehingga pendapatan masyarakat ini mencerminkan kemajuan ekonomi suatu masyarakat (Luminatang, 2013). Menurut Sukirno (2006), pendapatan adalah jumlah penghasilan yang diterima oleh penduduk atas prestasi kerjanya selama suatu periode tertentu, baik harian, mingguan, bulanan maupun tahunan. Pendapatan adalah jumlah penghasilan yang diterima selama periode tertentu berdasarkan jenis pekerjaan, prestasi dan lamanya bekerja. 
Masyarakat yang mempunyai penghasilan yang kecil, hasil dari pekerjaannya hanya untuk memenuhi kebutuhan sehari-hari. Untuk keluarga yang berpenghasilan menengah mereka lebih terarah kepada pemenuhan kebutuhan pokok yang layak seperti makan, pakaian, perumahan, pendidikan dan lain-lain. Sedangkan keluarga yang berpenghasilan tinggi dan berkecukupan mereka akan memenuhi segala keinginan yang mereka inginkan termasuk keinginan untuk menyekolahkan anak mereka ke jenjang pendidikan yang lebih tinggi. Masyarakat membutuhkan pembiayaan yang tidak kecil untuk menyekolahkan anak mereka, sehingga membutuhkan suatu pengorbanan pendidikan. Pengorbanan pendidikan itu dianggap sebagai suatu investasi di masa depan. Pembiayaan yang dialokasikan untuk pendidikan tidak semata-semata bersifat konsumtif, tetapi lebih merupakan suatu investasi dalam rangka meningkatkan kapasitas tenaga kerja untuk menghasilkan barang dan jasa. Pendidikan di sekolah merupakan salah satu bagian investasi dalam rangka meningkatkan kemampuan sumber daya manusia.

Hasil uji Mann Whitney menunjukkan bahwa bahwa tidak terdapat perbedaan pengaruh pendapatan orangtua terhadap tingkat literasi keuangan di kalangan siswa SMA Hidayatullah dan THPT Tran Nhan Tong karena diperoleh nilai asymp. sig. sebesar $0,489>0,005$, artinya tidak terdapat perbedaan pengaruh pendapatan orang tua terhadap literasi keuangan seseorang. Hasil penelitian ini sesuai dengan penelitian yang dilakukan oleh Homan, Hery Syaerul (2015) serta Margaretha dan Pambudhi (2015) yang menyimpulkan bahwa pendapatan orang tua tidak berpengaruh secara langsung terhadap literasi keuangan sehingga hipotesis ketiga tidak diterima. Tidak terdapat pengaruh pendapatan orang tua terhadap literasi keuangan seseorang.

\section{Perbedaan Tingkat Literasi Keuangan di Kalangan Siswa Indonesia dan Vietnam}

Chen dan Volpe (1998) menemukan tingkat literasi keuangan yang rendah pada peserta yang berusia 18-22 tahun. Alasan untuk rendahnya tingkat pengetahuan dapat dikaitkan dengan usia muda 18 sampai 22 tahun dari peserta atau di bawah 30 tahun sebagai mayoritas awal siklus dari hidup finansial mereka. Saat tahap siklus ini, mereka memiliki sejumlah masalah keuangan yang berkaitan dengan pengetahuan umum tentang keuangan, tabungan dan pinjaman, dan asuransi. Saat periode ini, sebagian besar pendapatan mereka dibelanjakan konsumsi daripada investasi. Sedangkan dalam proses mengatur keuangan, generasi ini kerap melakukan kesalahan yang sama. Banyak siswa yang belum memiliki tingkat literasi keuangan tinggi dengan didasarkan pada dimensi penerapan (application dimension). Gutter (2008) menyatakan bahwa pendidikan keuangan berpengaruh signifikan terhadap pengetahuan, sikap dan perilaku keuangan. Terkait rendahnya tingkat literasi keuangan siswa sekolah menengah di Indonesia, terdapat indikasi bahwa pendidikan finansial belum diterapkan pada mata pelajaran ekonomi di sekolah. Sedangkan di Vietnam, berdasarkan overview yang diterbitkan oleh State Bank of Vietnam, menunjukkan bahwa Vietnam membutuhkan kurikulum pendidikan keuangan yang menyeluruh karena belum adanya program dan kebijakan pendidikan keuangan di sekolah. Oleh karena itu, kedua negara sama-sama merencanakan penerapan kurikulum pendidikan keuangan di sekolah dalam waktu dekat secara menyeluruh. Hasil pengujian menunjukkan bahwa bahwa literasi kognitif SMA Hidayatullah dibanding THPT Tran Nhan Tong memiliki nilai signifanksi sebesar 0,081 > 0,05 ini berarti bahwa untuk literasi kognitif kedua sekolah secara signifikan tidak ada perbedaan. Untuk perbandingan variabel literasi afektif SMA Hidayatullah dibanding 
THPT Tran Nhan Tong, nilai signifikansi sebesar 0,33>0,05, ini berarti literasi afektif antara siswa SMA Hidayatullah dan THPT Tran Nhan Tong tidak terdapat perbedaan. Sehingga hipotesis keempat tidak diterima. Tidak terdapat perbedaan literasi keuangan antara siswa Indonesia dan Vietnam.

\section{KESIMPULAN}

Berdasarkan hasil penelitian menggunakan uji Mann-Whitney dapat disimpulkan bahwa, (1) berdasarkan hasil analisis deskriptif, perempuan cenderung memiliki literasi keuangan lebih tinggi dibanding laki-laki. Sedangkan melalui uji MannWhitney, terbukti bahwa terdapat perbedaan pengaruh variabel jenis kelamin terhadap tingkat literasi keuangan di kalangan siswa Indonesia dan Vietnam. (2) semakin tinggi pendidikan orangtua, maka anak akan semakin baik dalam mengelola keuangan. Hal ini mengindikasikan bahwa siswa yang memiliki orangtua berpendidikan tinggi akan cenderung berpengetahuan luas mengenai konsep keuangan sehingga mereka memiliki tingkat literasi keuangan yang tinggi pula. Pengujian menunjukkan bahwa bahwa terdapat perbedaan pengaruh pendidikan orangtua Indonesia dan Vietnam, (3) berdasarkan hasil pengujian dengan menggunakan uji Mann-Whitney terbukti bahwa tidak terdapat perbedaan pengaruh variabel pendapatan orangtua terhadap tingkat literasi keuangan di kalangan siswa Indonesia dan Vietnam, (4) berdasarkan hasil pengujian dengan menggunakan uji Mann-Whitney terbukti bahwa tidak terdapat perbedaan tingkat literasi keuangan di kalangan siswa Indonesia dan Vietnam.

\section{DAFTAR PUSTAKA}

Amaliyah, R. 2015. Analisis Faktor Yang Mempengaruhi Tingkat Literasi Keuangan di Kalangan UMKM Kota Tegal. Management Analysis Journal, 4(3), 252-257.

Atkinson, A., \& F. Messy. 2012. "Measuring Financial Literacy: Results of the OECD / International Network on Financial Education (INFE) Pilot Study", OECD Working Papers on Finance, Insurance and Private Pensions, No. 15, OECD Publishing.

Ansong, A., \& Gyensare, M. A. (2012). Determinants of university working- students' financial literacy at the University of Cape Coast, Ghana. International Journal of business and Management, 7(9), 126-133.

Ariadi, Riyan, Mariana Ing Malelak dan Dewi Astuti. 2015. Analisa Hubungan Financial Literacy dan Demografi Dengan Investasi, Saving, dan Konsumsi. Finesta, 3(1), 7-12.

Chen, H., \& Volpe, R. P. 1998. An Analysis of Personal Financial Literacy Among College Students. Financial Services Review, 7(2), 107-128.

Chen, H., \& Volpe, R. P. 1998. An Analysis of Financial Literacy Among College Students. Financial Services Review, 7(1), 107-128.

Cole, et. al. 2008. Financial Literacy, Financial Decisions, and the Demand for Financial Services: Evidence from India and Indonesia. Harvard Business School Working Paper 09-117.

Cameron, et al. 2013. Factors Associated with Financial Literacy among High School $\begin{array}{llll}\text { Students. } \quad \text { Porking } & \text { 13/05. }\end{array}$ 
http://www.mngt.waikato.ac.nz/repec/Wai/econwp/1305.pdf diakses pada tanggal 25 Februari 2014.

Gutter, et al. 2008. Financial Management Practices of College Student from States with varying Financial Education Mandates

https://tirto.id/kesalahan-mengatur-keuangan-ala-generasi-milenial-clUv (akses 2019) Homan, Hery Syaerul. 2015. Comparative Study of Student Financial Literacy and Its Demographic Factors. First International Conference on Economics and Banking (ICEB-15). Atlantis Press.

Huston, S.J. 2010. Measuring financial literacy. Journal of Consumer Affairs Vol. 44. Issue 2. Hal 296-316 The American Council on Consumer Interest.

Kharchenko, Olga. 2011. Financial Literacy in Ukraine: Determinants and Implication for Saving Behaviour. Ukraine: Kyiv School of Economic.

Keown, L. A. 2011. The Financial Knowledge of Canadians. Component of Statictics Canada Catalogue 11-008-X, 30-39.

Krishna, A., Rofi Rofaida, dan Maya Sri. 2010. Analisis Tingkat Literasi Keuangan di Kalangan Mahasiswa dan Faktor-Faktor yang Mempengaruhinya (Survey pada Mahasiswa Universitas Pendidikan Indonesia). Proceedings of The 4th International Conference on Teacher Education; Join Conference UPI \& UPSI Bandung, Indonesia, 8-10 November 2010 (November), 8-10.

Loke, Yiing Jia. 2015. Financial Knowledge and Behavior of Working Adult in Malaysia. The Journal of Applied Economic Research 9:1. Hal 18-38 SAGE Publication.

Lusardi, A., \& Mitchell, O. S. 2006. Baby Boomer Retirement Security: The Roles of Planning, Financial Literacy, and Housing Wealth. Journal of Monetary Economics

Lusardi, Olivia S. Mitchell, and Vilsa Curto. 2010. Financial Literacy Among the Young: Evidence and Imlications for Cunsumer Policy.

Lusardi, A., \& Mitchell, O. S. 2014. The Economic Importance of Financial Literacy: Theory and Ecidence. Journal of Economic Literature 2014, 52 (1).

Lumintang, Fatmawati M. 2013. Analisis Pendapatan Petani Padi di Desa TeepKecamatan Langowan Timur. Jurnal EMBA 991 Volume 1 No.3. Hal. 991998. Fakultas Ekonomi dan Bisnis Universitas Sam Ratulangi Manado.

Margaretha, Farah dan Reza Arief Pambudhi. 2015. Tingkat Literasi Keuangan Pada Mahasiswa S-1 Fakultas Ekonomi. Jurnal Manajemen dan Kewirausahaan. Vol.17, No. 1, Maret 2015, Hal. 76-85.

MasterCard. 2016. Newzealenders Best at Money Management and Continue to Top The

Nababan, D., dan Isfenti Sadalia. 2012. Analisis Personal Financial Literacy Dan Financial Behavior Mahasiswa Strata I Fakultas Ekonomi Universitas Sumatera Utara. Universitas Sumatera Utara. Hal. 1-16.

Otoritas Jasa Keuangan. 2016. Strategi Nasional Literasi Keuangan Indonesia: Revisit: 2017. Jakarta: Anggota Dewan Komisioner, Bidang Edukasi dan Perlindungan Konsumen.

Potrich, A. C. G., Vieira, K. M., \& Mendes-Da-Silva, W. 2016. Development of a financial literacy model for university students. Management Research Review, 39(3), 356-376.

PISA. 2012. Assessment and Analytical Framework: Mathematics, Reading, Science, Problem Solving and Financial Literacy. OECD Publishing Mokhlis, S. (2006) 
'The Influence of Religion on Retail Patronage Behaviour inMalaysia', Faculty of Management, Doctor of, p. 554. doi:10.1108/17590831111115268.

Rita, Maria Rio dan B. C. A. Pesudo. 2014. Apakah Mahasiswa Sudah Melek Keuangan?. Jurnal Dinamika Akuntansi, Keuangan dan Perbankan, Mei 2014, Volume 3. No. 1. Hal: 58-65

Sabri, M. F., Othman, M. A., Masud, J., Paim, L., MacDonald, M., \& Hira, T. K. 2008. Financial Behavior and Problems Among College Students in Malaysia: Research and Education Implication. Consumer Interest Annual, 54, 166-170.

Sanusi, Anwar. 2014. Metodologi Penelitian Bisnis. Cetakan Kelima. Jakarta:

Sugiyono. 2014. Metode Penelitian Kuantitatif, Kualitatif dan $R \& D$. Cetakan ke-20. Bandung: Alfabeta.

Shaari, N. A., Hasan, N. A., Mohamed, R. K. M. H., \& Sabri, M. A. J. M. 2013. Financial literacy: A study among the university student. Interdisciplinary Journal of Contemporary Research in Business, 5(2), 279-299.

Saputro, M.D.C. \& Nurhayati, F., 2014. Hubungan Antara Tingkat Pendidikan Orang Tua dengan Status Gizi Siswa (Studi Siswa SDN Campurejo 1 Bojonegoro). Jurnal Pendidikan Olahraga dan Kesehatan, 2(3), pp.627 - 630.

Santrock, J. W. 2007. Psikologi Pendidikan. Jakarta: Kencana.

Sukirno, S. 2006. Ekonomi Pembangunan: Proses, Masalah dan Dasar Kebijakan. Jakarta: Kencana Prenada Media Group

Sohn, Sang-Hee, So-Hyun Joo, John E. Grable, Seonglim Lee, Minjeung Kim.2012. Andolescents' Financial Literacy: The Role of Financial Socialization Agent, Financial Experience, and Money Attitude in Shapping Financial Among South Korean Youth. Journal of Andolesences 35. Hal 969-980. Elsevier Ltd. All rights reserved.

Taft, M. K., Hosein, Z. Z., \& Mehrizi, S. M.T. 2013. The relation between financial literacy, financial wellbeing and financial concerns. International Journal of Business and Management, 8(11), 63-75.

Widyawati, Irin. 2012. Faktor-faktor yang Mempengaruhi Literacy Financial Mahasiswa Fakultas Ekonomi dan Bisnis Brawijaya. Jurnal Akuntansi dan Pendidikan. Malang: Universitas Brawijaya 